5. Zasiekin M.D., Zhmailov V.O., Ponomarenko N.P., Zasiekin D.A. Efektyvnist detoksykuiuchykh preparativ pry vyroshchuvanni kurchat-broileriv. Suchasne ptakhivnytstvo, 2008, №9 (70). s. 2-5 (in Ukrainian).

6. Capko A.P., Shhedrov I.N. Perbaksan dlja obezvrezhevanija poverhnosti skorlupy tovarnyh jaic. Veterinarija, 2006, №9. s. 38-39 (in Russian).

7. Kotsiumbas I.Ia., Velichenko O.B. Perspektyvy zastosuvannia hipokhlorytiv u veterynarnii medytsyni. Monohrafiia. Lviv, TzOV, VF Afisha, 2009. 312 s.(in Ukrainian).

8. Doklinichni doslidzhennia veterynarnykh likarskykh zasobiv / Monohrafiia za red. d.v.n., prof. Kotsiumbasa I.Ia. Lviv, «Triada plius», 2006. 360 s.(in Ukrainian).

9. Klinichni doslidzhennia veterynarnykh preparativ ta kormovykh dobavok. Monohrafiia za red.d.v.n., prof. Kotsiumbasa I.Ia. - Lviv, TOV Vydavnychyi dim «SAM», 2013. 252 s.(in Ukrainian).

Рецензент - Б. В. Гутий, д. вет. н., професор, ЛНУВМБ імені С. З. Гжицького.

УДК 619:614. 48:636. 5

doi:10.36359/scivp.2019-20-2.43

\title{
ДОСЛІДЖЕННЯ ГОСТРОЇ ТА ХРОНІЧНОЇ ТОКСИЧНОСТІ ЗРАЗКІВ ГІНКГО БІЛОБА (GINKGO ВILOBA)
}

\author{
T. I. Фотіна, д-р вет. наук, професор, \\ Г. А. Фотіна, д-р вет. наук, професор, \\ С. М. Назаренко, канд. вет. наук, старший викладач, \\ A. I. Фотін, канд. вет. наук, дочент, \\ I. М. Коваленко, д-р біол. наук, професор, \\ Р. А. Ярощук, канд. с.-г. наук, доцент \\ Сумський національний аграрний університет, \\ вул. Герасима Кондратьєва, 160, м. Суми, 40021, Україна
}

У статті наведені результати гострої та хронічної токсичності зразків Гінкго Білоба. Встановлено, щзо при оцінці загального стану тварин через 30 хв. та 1 год після однократного введення екстракту у дозах 1000, 2500 та 5000 мг/кг відмічено зменшення рухливості як мишей, так і щурів, щуо минула на третю годину спостереження. Жодних інших ознак інтоксикації, зокрема з боку центральної та вегетативної нервової системи (бічне положення, зниження м'язового тонусу, порушення координації рухів, блефароптоз, гіперсалівачія тощо) не відмічено. Виходячи з результатів досліджень, екстракт Гінкго Білоба при підшкірному введенні білим мишам протягом 14 діб у терапевтичній дозі не спричиняв суттєвих змін загального стану, маси тіла, морфологічних та біохімічних показників крові.

Ключові слова: ГІНКГО БІЛОБА, ГОСТРА ТОКСИЧНІСТЬ, ФІЗІОЛОГІЧНИЙ СТАН, ХРОНІЧНА ТОКСИЧНІСТЬ, МОРФОЛОГІЧНІ ПОКАЗНИКИ КРОВІ, ЕКСТРАКТИ.

Гінкго білоба (Ginkgo biloba) - (гінкго дводольні, гінкго дволопатеве) - листяних дерев, відомих також під назвою адиантума, або кам'яного дерева, яке століттямі застосовується в 
східній медицині. Гінкго білоба - представник сімейства гінкгові (Ginkgoaceae). В якості лікарської сировини використовують листя, насіння і плоди Гінкго білоба.

Відносно Гінкго білоба накопичений великий клінічний досвід, який не викликає сумнівів в його ефективності при лікуванні церебральної недостатності, нейросенсорних порушень і захворюванні периферичних судин [1-3].

Гінкго білоба містить специфічні речовини - терпенлактони (терпенові лактони гінкголіди, білобаліди) і флавонглікозіди (флавоноїди - кверцетин, кемпферол, ізорамнетін, проантоціаніди), які впливають на процеси обміну речовин, нормалізують метаболічні процеси в клітинах, реологічні властивості крові і мікроциркуляцію.

Препарати і біологічно активні добавки (БАДи) на основі Гінкго білоба: стимулюють біосинтез ендотеліального релаксуючого фактора і простацикліну I2 в судинній стінці, чинять гальмівний вплив на фактор активації тромбоцитів, підвищують еластичність і міцність стінок кровоносних судин (ангіопротективна дія), перешкоджають агрегації еритроцитів i тромбоцитів, запобігають тромбози, в т. ч. мозкових і коронарних судин (антиагрегантна, антитромботична дія), сприяють розширенню дрібних артерій і підвищення тонусу вен, покращують капілярний кровообіг в органах і тканинах, покращують мозковий кровообіг i постачання мозку киснем i глюкозою, усувають циркуляторну недостатність атеросклеротичного походження, збільшують виживаність нейронів в умовах гіпоксії (вазорегулююау, венотонізуюча, антигіпоксична дія), сприяють зменшенню проникності судинної стінки як на рівні головного мозку, так і на периферії, гальмують розвиток травматичного або токсичного набряку головного мозку (протинабрякова дія), перешкоджають утворенню вільних радикалів і перекисного окиснення ліпідів клітинних мембран, стабілізують клітинні мембрани (антиоксидантна дія), нормалізують медіаторні процеси в центральній нервовій системі (ЦНС), впливають на вивільнення, зворотне захоплення і катаболізм нейромедіаторів і на їх здатність до зв'язування з мембранними рецепторами нейронів, стимулюють вивільнення i iнгібують зворотне захоплення норадреналіну і дофаміну (антидепресивна дія), підвищують чутливість постсинаптичних мускаринових рецепторів до ацетилхоліну (ноотропна дія), сприяють поліпшенню когнітивних функцій при церебральній недостатності: відновлюють пам'ять, здатність до концентрації уваги і навчання, мовні і рухові функції ЦНС, надають позитивний ефект при порушеннях периферичного кровообігу: облітеруючому атеросклерозі нижніх кінцівок, діабетичній мікроангіопатії, порушеннях слуху та зору (ретинопатії) в результаті вікових змін, еректильної дисфункції судинного генезу, інших станах, що супроводжуються хронічною ішемією периферичних тканин або органів [4-7].

При прийомі всередину екстракт гінкго білоба добре всмоктується зі шлунковокишкового тракту. Максимальна концентрація в плазмі крові досягається через 1-2 години. Період напіввиведення становить 4-5 годин. Визначення параметрів токсичності $\epsilon$ обов'язковим етапом у доклінічному вивченні перспективних лікарських сполук [8-10].

Проведені дослідження $є$ частиною комплексних наукових досліджень кафедр ветсанекспертизи, мікробіології, зоогігієни та безпеки і якості продуктів тваринництва, екології та ботаніки і садово-паркового та лісового господарства Сумського національного аграрного університету за тематичним планом науково-дослідної роботи «Біолого-екологічні особливості вирощування Ginkgo biloba L., як органічної сировини, у фармацевтичних цілях шляхом створення плантацій в умовах Північно східного Лісостепу України» (номер державної реєстрації: 0117U006533).

Мета досліджень - визначення гострої та хронічної токсичності різних зразків Гінкго Білоба.

Матеріали і методи. Дослідження проводили на базі лабораторії «Інноваційні технології та безпеки і якості продуктів тваринництва» та «Ветеринарна фармація» кафедри ветсанекспертизи, мікробіології, зоогігієни та безпеки і якості продуктів тваринництва 
факультету ветеринарної медицини Сумського національного аграрного університету. Фармако-токсикологічні дослідження проводили відповідно до положень, викладених у посібнику "Доклінічні дослідження ветеринарних лікарських засобів" (2006).

Відповідно до існуючих рекомендацій, використовували білих щурів та білих мишей. Листя Гінкго білоба збирали у вересні 2018 року у чотирьох місцях: зразок № 1 - парк Кияниця; зразок № 2 - теплиця; зразок № 3 - бокс; зразок № 4 - головний парк.

Внутрішньошлункове введення досліджуваних екстрактів у дозах, що у 10, 25 та 50 разів перевищували терапевтичну (1000, 2500 та 5000 мг/кг, відповідно), протягом 14 діб не призвело до загибелі тварин у жодній із груп (рис.).

Результати й обговорення. При оцінці загального стану тварин через 30 хв та 1 год після однократного введення екстракту у дозах 1000, 2500 та 5000 мг/кг відмічено зменшення рухливості як мишей, так і щурів, що минула на третю годину спостереження. Цей ефект найімовірніше міг бути зумовлений перевантаженням об'ємом уведеного розчину фітопрепарату. Жодних інших ознак інтоксикації, зокрема з боку центральної та вегетативної нервової системи (бічне положення, зниження м'язового тонусу, порушення координації рухів, блефароптоз, гіперсалівація тощо) не відмічено. Аналогічні результати були отримані і при дослідженні інших зразків. Але зразок № 4 зменшив рухливість тварин на чотири години (табл. 1). Отримані дані дозволяють віднести Гінкго Білоба до V класу токсичності за класифікацією Hodge та Sterner - практично нетоксичні речовини (LD50 > 5000 мг/кг).

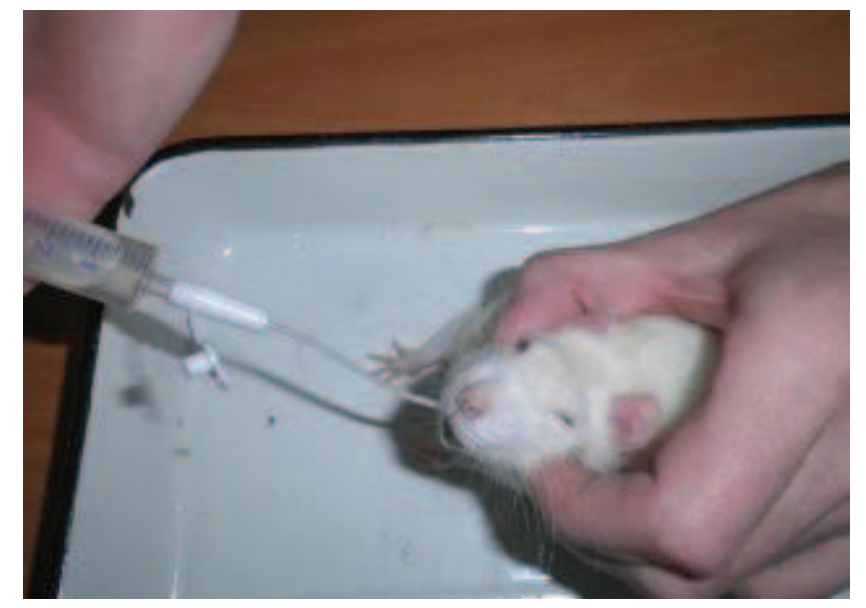

Рис. Внутрішньошлункове введення препарату

Визначення гострої токсичності Гінкго Білоба у тварин за однократного внутрішньошлункового введення зразка № 1

\begin{tabular}{|l|c|c|c|}
\hline \multirow{2}{*}{ Вид тварин } & \multirow{2}{*}{ Доза Гінкго білоба, мг/кг } & абсолютне число & Летальність \\
\cline { 3 - 4 } & & $0 / 3$ & 0 \\
\hline Миші & 1000 & $0 / 3$ & 0 \\
\hline Миші & 2500 & $0 / 3$ & 0 \\
\hline Миші & 5000 & $0 / 3$ & 0 \\
\hline Щури & 1000 & $0 / 3$ & 0 \\
\hline Щури & 2500 & $0 / 3$ & 0 \\
\hline
\end{tabular}

Примітки: у числівнику - кількість загиблих тварин, у знаменнику - кількість тварин у групі

Для виявлення можливої токсичної дії препарату на організм тварин на 21 та 31 добу від початку введення препарату на 10 мишах кожної групи вивчали антитоксичну функцію 
печінки за допомогою гексеналової проби і на інших 10 мишах кожної групи ставили пробу 3 плавання.

Визначення параметрів хронічної токсичності проводили на білих мишах. Для досліду за принципом парних аналогів підібрали 80 білих мишей 8-9-тижневого віку, масою 18-20 г, яких поділили на чотири групи по 20 тварин у кожній (три дослідні і одну контрольну). Мишам I, II, III та IV груп екстракт вводили під шкіру. V група тварин була контрольною, їм у період експерименту щоденно вводили 0,9 \% розчин натрію хлорид в дозі 0,1 мл/кг. Екстракт вводили щоденно впродовж 14-ти діб, зранку в один і той самий час. За дослідними тваринами проводили щоденне клінічне спостереження впродовж 30 діб, визначаючи клінічний стан, наявність апетиту, стан волосяного покриву та слизових оболонок, поведінкові реакції, рухову активність, норковий рефлекс, динаміку маси тіла, антитоксичну функцію печінки та ступінь оборотності спричинених препаратом ушкоджень. Проводили тест "відкрите поле", під час якого мишей висаджували в центральний квадрат прямокутного поля 140×70 см, розділеного на квадрати 10×10 cм, де у центрі певної їх кількості у довільному порядку в підлозі зроблені отвори ("нірки"), та фіксували латентний період виходу з нього, при цьому критерієм переходу тварини до іншого квадрата вважали переміщення через лінію, що розділяє квадрати, обох тазових кінцівок. Під час висаджування, перед фіксуванням показників, тварин накривали темним ковпаком для заспокоєння на 1 хв., враховували також кількість квадратів, куди зайшла тварина (горизонтальна рухова активність), кількість піднімань на тазові кінцівки ("вертикальна стійка"), кількість "нірок", які обнюхала тварина і в які заглянула, кількість умивань (актів грумінгу), уринацій і дефекацій (кількість болюсів). Всі тести проводили в трьох повторах. Отримані дані порівнювали з контрольними показниками. Показники динаміки маси тіла визначали шляхом порівняльної оцінки результатів зважування мишей перед початком та в кінці досліду. На наступну добу після останнього введення препарату, відбирали по 10 мишей з кожної групи, яких декапітували (під дією легкого ефірного наркозу), відбирали від них зразки крові для морфологічних та біохімічних досліджень.

Біохімічні дослідження крові проводили на аналізаторі "COBAS-E-MIRA". Після розтину відбирали внутрішні органи, зважували та вираховували вагові коефіцієнти їх маси, порівняно з тваринами контрольної групи.

При спостереженні за дослідними тваринами вірогідних змін у поведінці мишей не спостерігали (табл. 2).

Таблиия 2

Показники фізіологічного стану і активності білих мишей за 14-добового введення екстрактів Гінкго Білоба $(\mathrm{M} \pm \mathbf{m}, \mathbf{n}=\mathbf{2 0})$

\begin{tabular}{|l|l|l|c|}
\hline \multicolumn{1}{|c|}{ Групи тварин } & Апетит & Поведінкова реакція & $\begin{array}{c}\text { Вертикальна рухова } \\
\text { активність }\end{array}$ \\
\hline I група & задовільний & нірковий рефлекс збережений & $5,28 \pm 0,21$ \\
\hline II група & задовільний & нірковий рефлекс збережений & $5,20 \pm 0,41$ \\
\hline III група & задовільний & нірковий рефлекс збережений & $5,42 \pm 0,32$ \\
\hline IV група & задовільний & нірковий рефлекс збережений & $4,60 \pm 0,30$ \\
\hline V група контроль & задовільний & нірковий рефлекс збережений & $5,22 \pm 0,31$ \\
\hline
\end{tabular}

Апетит усіх мишей дослідних груп був задовільним і не відрізнявся від контрольних. У тварин, 4 групи впродовж 14-ти діб, дещо знижувалася рухова активність. Дослідження емоційно-поведінкових реакцій білих мишей після введення екстрактів протягом 14-ти діб у терапевтичній дозі не показало істотного впливу на нервову систему.

Встановлена орієнтовно-дослідна (кількість обнюхувань та заглядань) та емоційна (кількість дефекацій та болюсів) реакції дослідних тварин не відрізнялися тварин контрольної груп. Клінічний статус тварин дослідних та контрольної груп у процесі досліду залишався в межах фізіологічної норми. Відмічали незначне збільшення маси тіла дослідних і контрольних 
тварин протягом експерименту (табл. 3). Проте, найнижчим відсотком збільшення загальної маси був у мишей четвертої групи.

Таблиия 3

Динаміка маси тіла білих мишей у хронічному досліді під дією екстрактів Гінкго Білоба $(\mathrm{M} \pm \mathrm{m}, \mathrm{n}=20)$

\begin{tabular}{|l|c|c|c|c|c|}
\hline \multirow{2}{*}{ Група тварин } & \multicolumn{2}{|c|}{ До початку досліду } & \multicolumn{3}{c|}{ В кінці досліду } \\
\cline { 2 - 6 } & $\begin{array}{c}\text { загальна по } \\
\text { групі }\end{array}$ & маса тіла, г & $\begin{array}{c}\text { загальна по } \\
\text { групі }\end{array}$ & $\begin{array}{c}\text { середня однієї } \\
\text { тварини }\end{array}$ & $\begin{array}{c}\text { збільшення } \\
\text { загальної маси (\%) }\end{array}$ \\
\hline I & 384,4 & $19,81 \pm 0,38$ & 398,0 & $19,65 \pm 0,35$ & 106,20 \\
\hline II & 382,2 & $19,09 \pm 0,38$ & 392,2 & $19,15 \pm 0,37$ & 102,16 \\
\hline III & 382,4 & $19,18 \pm 0,44$ & 388,4 & $19,64 \pm 0,39$ & 103,15 \\
\hline IV & 382,6 & $19,08 \pm 0,42$ & 385,4 & $19,14 \pm 0,39$ & 101,17 \\
\hline V (контроль) & 382,5 & $19,07 \pm 0,39$ & 398,6 & $19,85 \pm 0,34$ & 104,14 \\
\hline
\end{tabular}

При визначенні морфологічних показників крові вірогідних змін у кількості лейкоцитів та еритроцитів, вмісті гемоглобіну та лейкограмі виявлено не було (табл. 4). Аналіз гематологічних показників свідчить про незначне зниження вмісту гемоглобіну в крові тварин четвертої групи.

Вміст у крові дослідних і контрольних тварин еритроцитів та лейкоцитів вірогідно не відрізнявся. Достовірних змін біохімічних показників порівняно з контрольними тваринами не виявлено.

У тварин IV групи спостерігалася тенденція до дещо напруженого функціонування системи виділення та печінки. При цьому відмічали підвищення вмісту сечовини на 0,18 та активності специфічних для печінки ферментів аланінамінотрансферази i аспартатамінотрансферази на 2,23 і 10,48, відповідно, порівняно з контролем.

Таблиия 4

Морфологічні показники крові білих мишей за визначення хронічної токсичності екстракту Гінкго Білоба $(\mathrm{M} \pm \mathrm{m}, \mathrm{n}=10)$

\begin{tabular}{|l|c|c|c|c|}
\hline \multirow{2}{*}{ Показники } & \multicolumn{4}{|c|}{ Групи тварин } \\
\cline { 2 - 5 } & I & II & III & IV \\
\hline Гемоглобін, Г/л & $168,2 \pm 3,6$ & $164,3 \pm 4,2$ & $164,7 \pm 4,7$ & $160,7 \pm 4,7$ \\
\hline Еритроцити Т/л & $8,2 \pm 0,1$ & $8,1 \pm 0,1$ & $8,0 \pm 0,3$ & $8,0 \pm 0,2$ \\
\hline Лейкоцити Г/л & $7,1 \pm 0,2$ & $7,2 \pm 0,3$ & $7,1 \pm 0,2$ & $7,3 \pm 0,2$ \\
\hline Еозинофіли, \% & $1,16 \pm 0,01$ & $1,06 \pm 0,02$ & $1,02 \pm 0,04$ & $1,01 \pm 0,05$ \\
\hline Нейтрофіли, \% & $29,5 \pm 2,4$ & $33,5 \pm 2,2$ & $32,4 \pm 2,1$ & $35,4 \pm 2,4$ \\
\hline Лімфоцити, \% & $59,9 \pm 3,2$ & $58,2 \pm 3,4$ & $58,8 \pm 2,6$ & $56,8 \pm 2,8$ \\
\hline Моноцити, \% & $0,60 \pm 0,1$ & $0,59 \pm 0,2$ & $0,59 \pm 0,1$ & $0,58 \pm 0,1$ \\
\hline
\end{tabular}

Вміст глюкози в крові тварин четвертої групи підвищився на 1,2 порівняно з контролем, що може вказувати на порушення глікогенсинтезуючої функції печінки, або підвищення інтенсивності окиснення вуглеводів. Вміст білка в сироватці крові експериментальних тварин всіх груп вірогідно не змінювався (табл. 5). У зв'язку з тим, що однією з причин підвищення рівня активності трансаміназних ферментів $€$ їх вихід із уражених органів та тканин у кров'яне русло, можна припустити про початок розвитку деструктивних процесів в гепатоцитах мишей, що отримували екстракт № 4 (вище вміст фенольних сполучень), тому що саме в печінці локалізується найбільша кількість аланінамінотрансферази.

Однак середнє значення цих показників не виходило за верхні межі норми для даного виду тварин. При патологоанатомічному дослідженні тварин у мишей всіх груп форма $\mathrm{i}$ величина печінки виглядала не зміненою. 
Біохімічні показники крові білих мишей за визначення хронічної токсичності препарату екстракту Гінкго Білоба $(\mathbf{M} \pm \mathbf{m}, \mathbf{n}=10)$

\begin{tabular}{|l|c|c|c|c|}
\hline \multirow{2}{*}{\multicolumn{1}{|c|}{ Показники }} & \multicolumn{4}{|c|}{ Групи тварин } \\
\cline { 2 - 5 } & I & II & III & IV \\
\hline Загальний білок, г/л & $56,34 \pm 2,30$ & $52,62 \pm 3,24$ & $52,32 \pm 1,33$ & $54,32 \pm 1,34$ \\
\hline Сечовина, ммоль/л & $5,27 \pm 0,22$ & $5,22 \pm 0,18$ & $5,26 \pm 0,24$ & $5,36 \pm 0,24$ \\
\hline Глюкоза, ммоль/л & $4,68 \pm 0,26$ & $5,18 \pm 0,22$ & $5,13 \pm 0,16$ & $5,83 \pm 0,26$ \\
\hline Лужна фосфотаза, од/л & $262,5 \pm 6,15$ & $266,4 \pm 5,19$ & $260,5 \pm 5,34$ & $264,5 \pm 6,34$ \\
\hline АлАТ, од/л & $84,86 \pm 2,44$ & $86,53 \pm 2,24$ & $85,51 \pm 2,16$ & $88,51 \pm 2,26$ \\
\hline АсАТ, од/л & $94,42 \pm 2,42$ & $101,34 \pm 3,24$ & $98,62 \pm 2,29$ & $104,62 \pm 3,29$ \\
\hline
\end{tabular}

У мишей четвертої групи печінка була збільшена у 1,5-2 рази. Відмінність також проявлялася при визначенні кольору органу. У контрольній, першій і другій дослідних групах Печінка однорідна, зафарбована у світло-коричневий колір, пружна, на розрізі структура збережена. У тварин інших груп печінка місцями неоднорідна, забарвлена у темно-коричневий колір з темно-вишневою смугастістю.

При проведенні макроскопічного дослідження селезінки у тварин четвертої дослідної групи орган був дещо змінений у розмірі. У всіх випадках орган мав видовжену форму. У мишей інших груп - темно-червоного кольору, краї загострені, на розрізі зі скребок пульпи незначний. Селезінка у тварин четвертої групи - світло-червоного кольору.

При макроскопічному дослідженні нирок у всіх групах тварин форма органа була не зміненою. При цьому, консистенція органів у тварин усіх груп була пружною, капсула з нирок знімалась легко.

\section{В И С Н О В К И}

1. Виходячи з результатів досліджень, екстракт Гінкго Білоба при підшкірному введенні білим мишам протягом 14 діб у терапевтичній дозі не спричиняв суттєвих змін загального стану, маси тіла, морфологічних та біохімічних показників крові.

2. Таким чином, відповідно до ГОСТ 12.1.007-76, екстракт Гінкго Білоба за ступенем токсичності належить віднести до нетоксичних речовин.

Перспективи досліджень. У подальшому планується розробка та випробування препарату, до складу якого входитиме екстракт Гінкго Білоба.

\section{INVESTIGATION OF ACUTE AND CHRONIC TOXICITY OF GINKGO BILOBA SAMPLES (GINKGO BILOBA)}

\section{T. I. Fotina, H. A. Fotina, S. M. Nazarenko, A. I. Fotin, I.N. Kovalenko, R. A. Yaroshchuk}

Sumy National Agrarian University, Gerasima Kondratieva str., 160, Sumy, 40021, Ukraine

\section{S U M M A R Y}

The article presents the results of acute and chronic toxicity of Ginkgo Biloba specimens. It was established that in assessing the general condition of animals after 30 minutes. and 1 year after single administration of the extract at doses of 1,000,2,500 and 5,000 mg / $\mathrm{kg}$, decreased mobility of both mice and rats, which occurred at the third hour of observation. There are no other signs of intoxication, in particular from the central and autonomic nervous system (lateral position, muscle tone reduction, movement coordination, blepharoptosis, hyperalsalivation, etc.). To detect possible 
toxic effects of the drug on the organism of animals at 21 and 31 days from the start of the drug in 10 mice each group studied the antitoxic function of the liver with hexenal test and in the other 10 mice in each group was placed a swimming test. The appetite of all mouse experimental groups was satisfactory and did not differ from the control ones. In animals, 4 groups for 14 days, somewhat decreased motor activity. The study of emotional-behavioral reactions of white mice after administration of extracts for 14 days in a therapeutic dose did not show a significant effect on the nervous system. In mice, the fourth group of liver was increased by 1.5-2 times. The difference is also manifested in determining the color of the organ. In the control group, the first and second experimental groups, the liver is homogeneous, painted in light brown color, elastic, on the section the structure is preserved. In animals of other groups of the liver in places is heterogeneous, colored in dark brown color with dark cherry stripe. During the macroscopic examination of the spleen in animals of the fourth experimental group, the organ was slightly changed in size. In all cases, the body had an elongated shape. In mice of other groups - dark red color, the edges are sharpened, on the cut from the scraper of the pulp is insignificant. Spleen in animals of the fourth group - light red color. In the macroscopic study of the kidneys in all animal groups, the form of the organ was not altered. In this case, the consistency of organs in animals of all groups was elastic, the capsule from the kidneys was removed easily. Based on the results of the studies, Ginkgo Biloba extract with subcutaneous administration to white mice for 14 days in a therapeutic dose did not cause significant changes in the general condition, body weight, morphological and biochemical blood parameters.

Keywords: GINKGO BILOBA, ACUTE TOXICITY, PHYSIOLOGICAL STATUS, CHRONIC TOXICITY, BLOOD MORPHOLOGICAL PARAMETERS, EXTRACTS.

\section{ИССЛЕДОВАНИЕ ОСТРОЙ И ХРОНИЧЕСКОЙ ТОКСИЧНОСТИ ОБРАЗЦОВ ГИНКГО БИЛОБА (GINKGO ВILOBA)}

\section{Т. И. Фотина, Г. А. Фотина, С. Н. Назаренко, А. И. Фотин, И. Н. Коваленко, Р. А. Ярощук}

Сумской национальный аграрный университет, ул. Герасима Кондратьева, 160, м. Суми, 40021, Украина

\section{А Н Н О Т А ЦИ Я}

В статье приведены результаты острой и хронической токсичности образцов Гинкго Билоба. Установлено, что при оценке общего состояния животных через 30 мин. и 1 ч после однократного введения экстракта в дозе 1000, 2500 и 5000 мг/кг отмечено уменьшение подвижности как мышей, так и крыс, за три часа наблюдения. Никаких других признаков интоксикации, в частности со стороны центральной и вегетативной нервной системы (боковое положение, снижение мышечного тонуса, нарушение координации движений, блефароптоз, гиперсаливация и т. п.) не отмечено. Исходя из результатов исследований, экстракт Гинкго Билоба при подкожном введении белым мышам в течение 14 суток в терапевтической дозе не вызывал существенных изменений общего состояния, массы тела, морфологических и биохимических показателей крови.

$\begin{array}{ccc}\text { Ключевые слова: ГИНКГО } & \text { БИЛОБА, ОСТРАЯ } & \text { ТОКСИЧНОСТЬ, } \\ \text { ФИЗИОЛОГИЧЕСКОЕ } & \text { СОСТОЯНИЕ, } & \text { ХРОНИЧЕСКАЯ } \\ \text { МОРФОЛОГИЧЕСКИЕ ПОКАЗАТЕЛИ КРОВИ, ЭКСТРАКТЫ. } & \text { ТОКСИЧНОСТЬ, }\end{array}$


1. Бурчинский С. Г. Препараты Гинкго в современной стратегии нейропротекции: возможности и перспективы (Обзор литературы) / С. Г. Бурчинский // Український вісник психоневрології. - 2011. - Т. 19, вип. 2. - С. 109-115.

2. Удовенко М. Б. Лікарські рослини, що володіють адаптогенними властивостями / М. Б. Удовенко, Г. В. Тарасенко // Тези доповідей XV Всеукраїнської наукової конференції молодих учених та студентів "Наукові розробки молоді на сучасному етапі". Т. 1 : Секція "Нові наукомісткі технології виробництва матеріалів, виробів широкого вжитку та спеціального призначення" : 28-29 квітня 2016 р. - К. : КНУТД, 2016. - С. 376.

3. Ginkgo extract EGb761 confers neuroprotection by reduction of glutamate release in ischemic brain, [Text] / A. Mdzinarishvili [et al.] // J. of Pharmacy and Pharmaceutical Sciences. 2012. - № 5. - P. 94-102.

4. Pharmaceutical Benefits of Ginkgo Biloba (Tree Of Life) [Text] / G. Singh1 [et al.] // J. of Biomedical and Pharmaceutical Research. - 2013. - № 2. - P. 15-21.

5. Crane P. Ginkgo: the tree that time forgot / P. Crane. - New Haven and London: Yale University Press, 2013. - $350 \mathrm{p}$.

6. Sasakia K. Chemistry and biological activities of Ginkgo biloba / K. Sasakia. - Hokkaido, 2007. -177 p.

7. Мищенко T. С. Применение экстракта гинкго билобы в лечении пациентов с хроническими сосудистыми заболеваниями головного мозга / Т. С. Мищенко, В Н. Мищенко, И. А. Лапшина. - Міжнародний неврологічний журнал. - 2015. - № 5 (75). - С. 130-134.

8. Кузнецова С. М. Применение экстракта гинкго билоба в системе реабилитации больных, перенесших инсульт / С. М. Кузнецова, В. В. Кузнецов, Д. В. Шульженко. Міжнародний неврологічний журнал. - 2016. - № 5 (83) - С. 111-114.

9. Леонтяк Г. П. Технологія вирощування гінкго дволопатевого (GINKGO BILOBA L.) і використання його в медицині / Леонтяк Г. П., Трет'якова С. А., Леонтяк Н. Г. // Науковий вісник НАУ : зб. наук. праць. - Сер.: Лісівництво. - К. : Вид-во НАУ. - 2004. - Вип. 70. C. 102-108.

10. Сініцина Л. В. Біологічні особливості Ginkgo biloba L. в умовах девастованих ландшафтів : автореф. дис. на здобуття наук. ступеня канд. біол. наук: спец. 03.00.05. - К., 2002. $-18 \mathrm{c}$.

\section{References}

1. Burchinsky S. G. Ginkgo preparations in the modern strategy of neuroprotection: opportunities and perspectives (Survey of literature) / S.G. Burchinsky // Ukrainian Bulletin of Psychoneurology. - 2011. - Vol. 19, no. 2. - P. 109-115. (in Ukrainian)

2. Burchinsky S. G. Ginkgo preparations in the modern strategy of neuroprotection: opportunities and perspectives (Survey of literature) / S.G. Burchinsky // Ukrainian Bulletin of Psychoneurology. - 2011. - Vol. 19, no. 2. P. 109-115. (in Ukrainian)

3. Ginkgo extract EGb761 confers neuroprotection by reduction of glutamate release in ischemic brain / A. Mdzinarishvili, [et al.] // J. of Pharmacy and Pharmaceutical Sciences. - 2012. № 5. - P. 94-102.

4. Pharmaceutical Benefits of Ginkgo Biloba (Tree Of Life) / G. Singh 1 [et al.] // J. of Biomedical and Pharmaceutical Research. - 2013. - № 2. - P. 15-21.

5. Crane P. Ginkgo: the tree that time forgot / P. Crane. - New Haven and London: Yale University Press, 2013. - 350 p.

6. Sasakia K. Chemistry and biological activities of Ginkgo biloba / K. Sasakia. - Hokkaido, 2007. $-177 \mathrm{p}$. 
7. Mishchenko T. S. Application of the Ginkgo biloba extract in the treatment of patients with chronic cerebrovascular diseases / T. S. Mischenko, V. N. Mishchenko, I. A. Lapshina - International Neurological Magazine. - 2015 - № 5 (75). - P. 130 - 134. (in Ukrainian)

8. Kuznetsova S. M. Application of Ginkgo biloba extract in the system of rehabilitation of patients undergoing stroke / S. M. Kuznetsova, V. V. Kuznetsov, D.V. Shulzhenko - International Neurological Magazine. - 2016 - № 5 (83) - P. 111 - 114. (in Ukrainian)

9. Leontyak G. P. Ginkgo biloba cultivation technology (GINKGO BILOBA L.) and its use in medicine / Leont'yak G. P., Tretyakova S. A., Leont'yak N. G. // Scientific bulletin of NAU: Sb. sciences works - Sir: Arboriculture. - K.: View of the NAU. - 2004. № 70. - P. 102 108. (in Ukrainian)

10. Sinitsina L.V. Biological features of Ginkgo biloba L. in conditions of virgin landscapes: author's abstract. dis for the sciences. Degree Candidate biology Sciences: special 03.00.05. - K., 2002. - 18 p. (in Ukrainian).

Рецензент - А. В. Березовський, д. вет. н., професор, Сумський національний аграрний університет. 